$$
\text { DOE/PC/95207--T3 }
$$

NEW CATALYSTS FOR COAL PROCESSING: METAL CARBIDES AND NITRIDES

Type of report

Reporting Period:

Principal Investigators:

Date of Report:

DOE Award Number:

Institute:
Seminannual

July 17, 1996-January 17 (Third semiannual)

S. Ted Oyama \& David F. Cox

January 5,1997

DE-FG22-95PC95207

Virginia Polytechnic Institute \& State University

Department of Chemical Engineering

Blacksburg, VA 24061-0211

Grant Date:

July 17,1995

Contracting Officer's Rep: Udaya Rao 


\section{DISCLAMMER}

Portions of this document may be illegible in electronic image products. Images are produced from the best available original document. 


\title{
NEW CATALYSTS FOR COAL PROCESSING: METAL CARBIDES AND NITRIDES THIRD SEMIANNUAL REPORT
}

\author{
S. Ted Oyama \& David F. Cox
}

\section{Disclaimer}

This report was prepared as an account of work sponsored by an agency of the United States Government. Neither the United States Government nor any agency thereof, nor any of their employees, makes any warranty, express or implied, or assumes any legal liability or responsibility for the accuracy, completeness, or usefulness of any information, apparatus, product, or process disclosed, or represents that its use would not infringe privately owned rights. Reference herein to any specific commercial product, process, or service by trade name, trademark, manufacturer, or otherwise does not necessarily constitute or imply its endorsement, recommendation, or favoring by the United States Government or any agency thereof. The views and opinions of authors expressed herein do not necessarily state or reflect those of the United States
Abstract
Unsupported molybdenum nitride $\left(\mathrm{MO}_{2} \mathrm{~N}\right)$ and molybdenum carbide supported on alumina $\left(\mathrm{Mo}_{2} \mathrm{C} / \mathrm{Al}_{2} \mathrm{O}_{3}\right.$ ) were compared against commercial sulfided $\mathrm{MoS}_{2} / \mathrm{Al}_{2} \mathrm{O}_{3}$ and $\mathrm{Ni}-\mathrm{Mo}-\mathrm{S} / \mathrm{Al}_{2} \mathrm{O}_{3}$ for hydrotreating coal-derived gas oil at $633 \mathrm{~K}\left(360^{\circ} \mathrm{C}\right)$ and $13.7 \mathrm{MPa}(2000 \mathrm{psig})$. When the catalytic rates were compared on the basis of active sites measured by chemisorption, the nitrides and carbides were estimated to have activities as much as five times that of $\mathrm{Ni}-\mathrm{Mo}-\mathrm{S} / \mathrm{Al}_{2} \mathrm{O}_{3}$ and $\mathrm{MoS}_{2} / \mathrm{Al}_{2} \mathrm{O}_{3}$. The comparison was based on sites titrated by $\mathrm{CO}$ on the carbide and nitride and by $\mathrm{O}_{2}$ on the sulfided catalysts. The gas oil product quality from the carbide and nitride catalysts was significantly better than the thermal blank, indicating that the materials were active under practical hydrotreating conditions. X-ray photoelectron spectroscopy analysis after reaction of the $\mathrm{Mo}_{2} \mathrm{~N}$ and $\mathrm{Mo}_{2} \mathrm{C} / \mathrm{Al}_{2} \mathrm{O}_{3}$ catalysts indicated that surface sulfiding was not extensive.

\section{Table of Contents}

Title Page

Disclaimer

Abstract

Table of Contents

Executive Summary Introduction

Results and Discussion

Conclusion

References 


\section{Executive Summary}

Catalytic hydroprocessing of oil derived from coal to remove heteroatoms and to saturate aromatic rings is a crucial first step in the refining of these hydrocarbon resources. As the quality of available feeds decreases with time there are increasing needs to develop better catalysts for hydrotreating [1,2]. This report describes hydrotreating of a low sulfur, coal derived liquid at industrial conditions, $633 \mathrm{~K}\left(360^{\circ} \mathrm{C}\right)$ and $13.7 \mathrm{MPa}(2000 \mathrm{psig})$ in a three-phase flow reactor with a new class of catalysts: supported and unsupported molybdenum carbide and nitride. The new catalysts have activity surpassing that of a commercial sulfided $\mathrm{Ni}-\mathrm{Mo} / \mathrm{Al}_{2} \mathrm{O}_{3}$ catalyst.

\section{Introduction}

Catalysts for hydrotreating reactions have traditionally been sulfides of molybdenum with cobalt and nickel promoters $[3,4,5]$. This report presents the performance of a new type of catalyst: carbides and nitrides of molybdenum. These materials differ substantially from previous molybdenum compounds in being metallic interstitial alloys of carbon and nitrogen and not insulating layered compounds. Interest in their catalytic properties is a result of their recent availability in very high surface area form $[6,7]$.

The present study is motivated by a previous report that the carbides and nitrides are active for denitrogenation of quinoline under batch conditions [8,9]. This high activity in hydroprocessing reactions have been confirmed in a number of studies using model feeds $[10,11,12,13]$. Here, the performance of the compounds for hydroprocessing is reported using a real feedstock derived from coal liquids. Particular attention is placed on hydrodenitrogenation (HDN). Activities of the molybdenum carbide and nitride catalysts are compared with that of

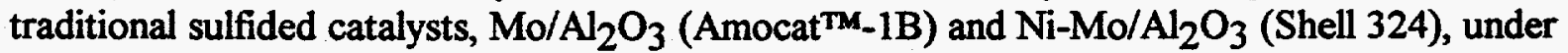
identical conditions. A blank reactor packed with inert alundum chips served as a thermal control.

\section{Results and Discussion}

The molybdenum carbide and nitride catalysts were prepared as reported earlier [14]. The molybdenum carbide was supported on $\gamma-\mathrm{Al}_{2} \mathrm{O}_{3}$ by impregnating the support with an aqueous ammonium molybdate solution and carburizing the dried solid in a $20 \% \mathrm{CH}_{4} / \mathrm{H}_{2}$ reactant stream. The molybdenum nitride was prepared by the temperature programmed reaction of molybdenum trioxide in a flowing ammonia stream. The carbide and nitride catalysts were passivated in $1 \%$ $\mathrm{O}_{2} / \mathrm{He}$ after preparation.

Reactivity was measured in stainless steel $7.9 \mathrm{~mm} / 14.3 \mathrm{~mm}$ (ID/OD) reactors with the catalysts (14/20 mesh) physically mixed with alundum chips (14/20 mesh) to a bed volume of 11 $\mathrm{cm}^{3}$ and held by plugs of the same chips. The reactors were operated at $633 \mathrm{~K}$ and $13.7 \mathrm{MPa}$ with cocurrent upward flow of oil $\left(4 \mathrm{~cm}^{3} \mathrm{~h}^{-1}\right)$ and $\mathrm{H}_{2}\left(106 \mu \mathrm{mol} \mathrm{s}{ }^{-1}, 159 \mathrm{~cm}^{3}(\mathrm{STP}) \mathrm{min}^{-1}\right)$. Such upward flow ensures good catalyst contacting and operation in the kinetic regime with a liquid saturated in hydrogen. Temperatures were monitored by movable thermocouples mounted axially along the length of the reactor.

Catalysts were packed into the reactor to give the same number of active sites when possible. Active sites were counted by the static chemisorption of $\mathrm{O}_{2}$ in the case of Ni-Mo$\mathrm{S} / \mathrm{Al}_{2} \mathrm{O}_{3}$ and $\mathrm{MoS}_{2} / \mathrm{Al}_{2} \mathrm{O}_{3}$ and $\mathrm{CO}$ chemisorption in the case of molybdenum carbide and nitride 
The coal-derived feed is referred to as a coal-derived gas oil because it has a similar boiling point range to the intermediate stream of the same name found in petroleum refining. The coal gas oil was obtained from the Wilsonville coal liquefaction facility (Run 257). The catalysts showed no signs of deactivation for the duration of the run of 260 hours.

Table 1 gives a comprehensive summary of the product qualities after 260 hours on oil. The molybdenum carbide and nitride catalysts yield products that are significantly better than those from the blank (thermal) reactor. The blank product characteristics are close to those of the feed. Furthermore, all the measurements indicate product qualities are higher than those from sulfided $\mathrm{Ni}-\mathrm{Mo}-\mathrm{S} / \mathrm{Al}_{2} \mathrm{O}_{3}$ and $\mathrm{MoS}_{2} / \mathrm{Al}_{2} \mathrm{O}_{3}$. Notable is that there was little aromatic saturation, as measured by C13 NMR, or change in the ratio of $\mathrm{H} / \mathrm{C}$ achieved by all but $\mathrm{Mo}_{2} \mathrm{~N}$ at these process conditions.

Table 1

Analysis of the Product after 260 Hours on Coal Gas Oil

\begin{tabular}{|l|c|c|c|c|c|c|}
\hline & $\mathrm{Mo}_{2} \mathrm{~N}$ & $\mathrm{Mo}_{2} \mathrm{C} / \mathrm{Al}_{2} \mathrm{O}$ & $\mathrm{NiMoS} / \mathrm{Al}_{2} \mathrm{O}$ & $\mathrm{MoS}_{2} / \mathrm{Al}_{2} \mathrm{O}_{3}$ & Blank & Feed \\
\hline $\mathrm{C} / \mathrm{wt} \%$ & 88.76 & 88.64 & 88.68 & 88.64 & 88.35 & 88.54 \\
\hline $\mathrm{H} / \mathrm{wt} \%$ & 11.05 & 10.83 & 10.79 & 10.77 & 10.73 & 10.73 \\
\hline $\mathrm{H} / \mathrm{C}$ ratio & 1.50 & 1.47 & 1.46 & 1.46 & 1.46 & 1.46 \\
\hline $\mathrm{S} / \mathrm{ppm}$ & 28 & 49 & 38 & 55 & 84 & 116 \\
\hline $\mathrm{N} / \mathrm{ppm}$ & 1730 & 2410 & 2890 & 2900 & 3480 & 3580 \\
\hline Aromatics / wt\% & 29.6 & 32.1 & 32.3 & 33.0 & 33.4 & 33.5 \\
\hline
\end{tabular}

Table 2 compares relative pseudo first-order rate constants for desulfurization, denitrogenation, and aromatic saturation relative to $\mathrm{Ni}-\mathrm{Mo}-\mathrm{S} / \mathrm{Al}_{2} \mathrm{O}_{3}$. The pseudo first-order rate constants $(\mathrm{k})$ themselves are obtained by integrating the expression $V=F_{0} \int d x / k C$ where $F_{0}$ is the molar flow rate, $k$ is the rate constant and $C$ is the concentration. This results in the expression, $k=(1 / \tau) \ln \left(C_{\text {feed }} / C_{\text {product }}\right)$, where $\tau=V / v_{o}=11 \mathrm{~cm}^{3} / 159 \mathrm{~cm}^{3} \mathrm{~s}^{-1}=0.069 \mathrm{~s}$. The pseudo rate constants are further normalized by the amount of active sites in each of the reactors.

A concern with using molybdenum carbide and nitride for hydrotreating applications is that the formation of molybdenum sulfide is thermodynamically favored in the presence of sulfur $[14,15]$. Consequently, the catalysts were characterized after reaction by XRD and XPS analyses. XRD did not show the presence of crystalline $\mathrm{MoS}_{2}$ at the detection limit concentration of $1 \mathrm{wt} \%$ on the molybdenum nitride (molybdenum carbide was not examined). The results from XPS are shown in Table 3. 
Table 2

Estimated Relative First-Order Rate Constants" per "Active Site"

\begin{tabular}{|c|c|c|c|}
\hline Catalyst & Desulfurization & Denitrogenation & Aromatic saturation \\
\hline $\mathrm{Mo}_{2} \mathrm{~N}$ & 1.3 & 3.4 & 3.4 \\
\hline $\mathrm{Mo}_{2} \mathrm{C} / \mathrm{Al}_{2} \mathrm{O}_{3}{ }^{\mathrm{c}}$ & 2.1 & 5 & 3.1 \\
\hline $\mathrm{MoS}_{2} / \mathrm{Al}_{2} \mathrm{O}_{3}$ & 0.67 & 0.98 & 0.41 \\
\hline $\mathrm{Ni}-\mathrm{Mo}-\mathrm{S} / \mathrm{Al}_{2} \mathrm{O}_{3}$ & 1 & 1 & 1 \\
\hline \multicolumn{4}{|c|}{$\begin{array}{l}\text { Calculated by }\left[\operatorname{In}(\mathrm{co} / \mathrm{c})_{i}\right] /\left[\operatorname{In}(\mathrm{co} / \mathrm{c})_{\mathrm{Ni}-\mathrm{Mo}}\right] \text {. } \\
\text { As titrated by } \mathrm{CO} \text { for the carbide and nitride and by } \mathrm{O} \text { for the sulfides. } \\
\text { Rate constant corrected by } 718 / 268 \text {, the ratio of } \mu \mathrm{mol} O \text { uptake by } \mathrm{Ni}-\mathrm{Mo} \text { to } \mathrm{CO} \text { uptake by } \\
\mathrm{MO}_{2} \mathrm{C} / \mathrm{Al}_{2} \mathrm{O}_{3} \text { in the reactors. }\end{array}$} \\
\hline
\end{tabular}

Table 3

Surface Composition Measured by XPS

\begin{tabular}{|c|c|c|c|c|c|c|c|c|}
\hline \multicolumn{9}{|c|}{$\mathrm{Mo}_{2} \mathrm{~N} / \mathrm{mol} \%$} \\
\hline & C & 10 & Mo & $\mathrm{S}$ & $\mathrm{N}$ & $\mathrm{Na}$ & $\mathrm{Al}$ & $\mathrm{Si}$ \\
\hline fresh & 24.4 & 29.2 & 21.3 & - & 25.0 & - & - & - \\
\hline used & 46.8 & 28.6 & 12.5 & 3.2 & 7.9 & - & - & 0.9 \\
\hline reduced & 12.8 & 42.9 & 26.2 & - & 18.1 & - & - & - \\
\hline \multicolumn{9}{|c|}{$\mathrm{Mo}_{2} \mathrm{C} / \mathrm{Al}_{2} \mathrm{O}_{3} / \mathrm{mol} \%$} \\
\hline fresh & 4.8 & 37.8 & 1.9 & - & -- & - & 55.5 & - \\
\hline used & \begin{tabular}{|l|}
33.4 \\
\end{tabular} & 40.0 & 2.0 & \begin{tabular}{|l|}
1.4 \\
\end{tabular} & 0.8 & 0.2 & 22.2 & - \\
\hline reduced & 3.1 & 60.4 & 4.7 & -- & - & - & \begin{tabular}{|l|}
31.7 \\
\end{tabular} & - \\
\hline
\end{tabular}

The XPS data for molybdenum nitride catalyst withdrawn from the reactor reported in Table 3 indicates a sulfur-to-molybdenum ratio of $3.2 / 12.5=0.26$, well below the expected ratio of 2 should $\mathrm{MoS}_{2}$ have been formed within the sampling depth for XPS (roughly 1-2 nm). Consequently, it does not appear that extensive sulfiding of the molybdenum nitride occurred during its use. The same argument and conclusion applies to $\mathrm{Mo}_{2} \mathrm{C} / \mathrm{Al}_{2} \mathrm{O}_{3}$. It cannot be ruled out, however, that some $\mathrm{MoS}_{2}$ was formed at the topmost atomic layers of the nitride (carbide) crystallite surface. An analysis of the oxidation states of molybdenum in the used molybdenum 
carbide and nitride catalysts indicates that not all the molybdenum was reduced to the $\mathrm{Mo}^{+4}$ state (only $63 \%$ in the case of $\mathrm{Mo}_{2} \mathrm{~N}$ ) during the pretreatment.

It is clear from the results that molybdenum carbide and nitride are active for hydrotreating under practical industrial conditions. While the feedstocks were coal-derived liquids, it is very likely that molybdenum nitride and carbide will exhibit similar catalytic properties for hydrotreating petroleum-derived liquids.

\section{Conclusions}

It is significant that for a reasonable attempt at counting sites ( $\mathrm{CO}$ adsorption on the nitrides and carbides and static $\mathrm{O}_{2}$ adsorption on the sulfides) that $\mathrm{MO}_{2} \mathrm{~N}$ and $\mathrm{MO}_{2} \mathrm{C} / \mathrm{Al}_{2} \mathrm{O}_{3}$ compare very favorably with a commercial sulfided $\mathrm{Ni}-\mathrm{Mo} / \mathrm{Al}_{2} \mathrm{O}_{3}$ catalyst. It also noteworthy that the XPS data indicate that $\mathrm{Mo}_{2} \mathrm{~N}$ and $\mathrm{Mo}_{2} \mathrm{C}$ are not detectably sulfided despite operation at high pressures, temperatures, and with real hydrocarbon feeds.

\section{Acknowledgments}

This work was carried out in collaboration with D. J. Sajkowski of Amoco Oil Corporation.

\section{References}

1. R. Sivasubramanian and J.R. Katzer, Catal. Rev. Sci. Eng. 20 (1979) 155.

2. T. C. Ho, Catal. Rev. Sci. Eng. 30 (1988) 117.

3. F. E. Massoth and G. Muralidhar, in H. F. Barry and P. Mitchell (Eds.) Proc of the Climax Fourth Int. Conf. on the Chemistry and Uses of Molybdenum, Climax Molybdenum Company, Ann Arbor, Michigan, p. 343, 1982.

4. H. Topsoe and B. S. Clausen, Catal. Rev. Sci. and Eng. 26 (1984) 395.

5. R. R. Chianelli Catal. Rev. Sci. Eng. 26 (1984) 361.

6. L. Volpe, S. T. Oyama and M. Boudart, in Preparation of Catalysts III, Elsevier, Amsterdam, 1983.

7. L. Volpe and M. Boudart, J. Solid State Chem. 59 (1985) 332.

8. J. C. Schlatter, S. T. Oyama, J. E. Metcalf, III, R. M. Lambert, Jr., Ind. Eng. Chem. Res. 27 (1988) 1648.

9. S. T. Oyama, J. C. Schlatter, J. E. Metcalf, III, and J. M. Lambert, Jr., International Chemical Congress of Pacific Basin Societies, Symposium on "Upgrading Strategies for Heavy Oil and Sands Bitumen", Honolulu, Hawaii, Dec, 1989.

10. C. W. Colling and L. T. Thompson, J. Catal., 146 (1994) 193.

11. E. J. Markel and J. W. Van Zee, J. Catal. 126 (1990) 643.

12. H. Abe and A. T. Bell, Catal. Lett., 18 (1993) 1.

13. M. Nagai, T. Miyao and T. Tuboi, Catal. Lett., 18 (1993) 9.

14. S. T. Oyama, J. C. Schlatter, J. E. Metcalf, J. M. Lambert, Ind. Eng. Chem. Res., 27 (1988) 1639.

15. R. B. Levy, in Advanced Materials in Catalysis, J. J. Burton and R. L. Garten, Eds., p. 101, 1977. 